\title{
The Factors Affecting Tourist Visits at Owabong Waterpark in Bojongsari Sub- district of Purbalingga
}

\author{
By: \\ Riska Eristiana Anindya Putri ${ }^{1)}$, Rusmusi Indranjoto ${ }^{2)}$ \\ ${ }^{1,2)}$ Faculty of Economics and Business, Universitas Jenderal Soedirman \\ ${ }^{2)}$ Email: rusmusiimpgusindra@yahoo.com
}

\begin{abstract}
This research aimed to determine the effect of income, travel cost, distance and visitor age on the number of tourist visit to Owabong Waterpark. This research is a survey research to visitors of Owabong Waterpark using accidental sampling method. Qualitative and quantitative data was derived questionnaire based interview technique. This research used multiple linear regression analysis with double log model. The result indicated that income had a positive effect on tourist visits at Owabong Waterpark. Travel cost and distance have insignificant effect on tourist visits at Owabong Waterpark. Age had insignificant effect on tourist visits at Owabong Waterpark. The implication of this research for the management of Owabong Waterpark is to continously improve the existing facilities and infrastructures to maintain the quality of tourist attraction, always innovate various vehicles attracting the visitors, conduct promotions such as discounted ticket to reach all income groups, conduct more vigorous promotions, especially in social media to be better known by the community outside Purbalingga so that Owabong Waterpark is not only visited by local tourists, but also foreign tourists.
\end{abstract}

Keywords: Income, Travel Cost, Distance, Age, Social Media.

\begin{abstract}
ABSTRAK
Penelitian ini bertujuan untuk mengetahui pengaruh pendapatan, biaya perjalanan, jarak dan usia pengunjung terhadap jumlah kunjungan wisatawan ke Owabong Waterpark. Penelitian ini merupakan penelitian survei kepada pengunjung Owabong Waterpark menggunakan metode accidental sampling. Data kualitatif dan kuantitatif adalah kuesioner yang diturunkan berdasarkan teknik wawancara. Penelitian ini menggunakan analisis regresi linier berganda dengan model double log. Hasilnya menunjukkan bahwa pendapatan memiliki efek positif pada kunjungan wisatawan di Owabong Waterpark. Biaya perjalanan dan jarak tidak berpengaruh signifikan terhadap kunjungan wisatawan di Owabong Waterpark. Umur memiliki efek yang tidak signifikan pada kunjungan wisatawan di Owabong Waterpark. Implikasi dari penelitian ini terhadap pengelolaan Owabong Waterpark adalah dengan terus meningkatkan fasilitas dan infrastruktur yang ada untuk mempertahankan kualitas objek wisata, selalu berinovasi berbagai kendaraan yang menarik pengunjung, melakukan promosi seperti tiket diskon untuk menjangkau semua kelompok pendapatan, melakukan lebih banyak promosi yang kuat, terutama di media sosial untuk lebih dikenal oleh masyarakat di luar Purbalingga sehingga Owabong Waterpark tidak hanya dikunjungi oleh wisatawan lokal, tetapi juga wisatawanasing.
\end{abstract}

Kata Kunci: Pendapatan, Biaya Perjalanan, Jarak, Usia, Media Sosial.

\section{INTRODUCTION}

Tourism is a temporary tour process of one or more persons to another place outside their environment (Li et al., 2018). The term 'tourism' is closely related to the definition of tour that is a 
temporary change of residence of a person outside his other residence for some reasons and not engaged in a wage-earning. Purbalingga Regency is one of the regencies in Central Java that is very aggressive in developing the tourism as the main sector (Puspita et al., 2016). The tourism sector in Purbalingga has grown by utilizing the natural resources and creating artificial tourist attraction. Bojongsari Water Attraction or better known as Owabong Waterpark is on of the artificial tourist attractions that becomes the mainstay of Purbalingga Regency (Ahmadia, 2017). As it is the most complete water tourism in Purbalingga Regency. The site provides various types of vehicles, such as Olympic swimming pool, waterboom, water bucket fall, lazy river, tsunami free pool, wave pool sagara, game pool, Sesat pool, water party pool, gokart circuit, flying fox, 4D theatre, rafting adventure, Anjungan Dirgantara, fish therapy, hot water pool, and women's pool.

The number of tourists visiting the tourist attraction in Purbalingga Regency increased during 2013 to 2016. In 2014, the number of tourist visits decreased by 9.50 percent from the previous year. This is consistent with the growth of tourist visits in Central Java in 2013 which only grew by 1.51 percent. In addition, the political condition and the change of government are suspected to be factors of declining interest of a person to visit several tourist attractions, especially on foreign tourists. Furthermore, the number of tourists visiting Purbalingga were increasing in 2015 and 2016. The highest number of visitors was in 2016 by 1,602,178 person, meaning that there was an increase of 19.3 percent from the previous year reaching 1,343,355 person. Based on data on tourist visits in Purbalingga district in 2013 to 2016 shows that the highest number of tourist visits is at Owabong Waterpark. During 2013 to 2016, the number of visitors at Owabong Waterpark tended to increase. Significant increase occurred from 2015 to 2016 with a total visitor of 1,762,730 or there was an increase of 22.21 percent. While the lowest number of tourist visits was at Petilasan Ardilawet. Although the number of tourist visits is in the lowest category, but there is a positive trend from year to year. In 2016, the number of tourist visits at Petilasan Ardilawet was 7,890 person or there was an increase of 39.6 percent from the previous year.

The fluctuating number of tourist visit at Owabong Waterpark is a reflection of the uncertainty of the number of visitors visiting Owabong Waterpark. Therefore, the effort to increase the tourist visit at Owabong Waterpark can be performed by increasing the number of tourist visit to Owabong Waterpark or by increasing the frequency of visits who have been to Owabong Waterpark.

\section{LITERATURE REVIEW}

\section{Demand}

Demand is the relationship between the quantity of a commodity that producers wish to sell at various prices during a certain period (Raisova and Durcova, 2014). The quantity demanded is a function of the price of commodity, meaning that the quantity of goods demanded by consumer depends on the price of the goods.

Demand function indicates the relationship between the quantity of goods demanded as the dependent variable $(\mathrm{Qx})$ and the independent variables (price, income, taste, advertisement, etc.) which may affect the dependent variable. Then, it can be written in equation as follows (Trenggonowati, 2011):

$$
Q X=f(P x, M, P y, T, A, O, E, W)
$$

Where:

$Q x$ : the number of goods $x$ demanded

$P x$ : price of commodity $X$

$M$ : money-individual nominal income

Py : price/other commodity price $Y$

$\mathrm{T}$ : taste, individual taste

A : advertisement

O : outlet/store

E : expectation

W : weather 


\section{Tourism}

In essence, tourism is the activity of people touring and staying in places outside their usual environment. Motivation for tourism are due to various interests, such as economic, politic, religious, health interests, and other interests such as curiosity, experience, and learning. The term of tourism is closely related to the notion of tour, that is, a change of temporary residence of a person outside his residence for some reasons and not engaged in a wage-earning activity.

Tourism is one type of a new industry capable of generating rapid economic growth in the provision of employment, income generation, living standard and stimulating other productivity sectors. Furthermore, as a complex sector, it includes classic industries, such as handicrafts and souvenir industries.

\section{HYPOTHESIS}

\section{Income}

According to Cai and Evans (2018), tourism demand is affected by income and price. In the case of an increase in income compared with relatively constant price, the effect on most types of tourism and tourist destinations is positive. Income is highly influential on the decision of tourists to make a visit to the tourist attraction. The purchasing power on the demand curve is determined by the survival level and tour intensity. In other words, the greater the person's income, the more likely the person will tour. Therefore, there is a significant relationship between the amount of income and the number of tourist visit, where changes in the amount of income will cause changes in tourist visit. Based on the theory, it can be formulated a hypothesis as follows:

$\mathrm{H} 1$ : Income has a positive effect on the number of tourist visits.

\section{Travel Cost to Tourist Attraction}

According to Mc. Intosh (1995: 298), the higher the economic distance, the higher the resistance for that purpose, and consequently, the lower the demand. If cost of time and tour can be reduced, the demand will rise. Economic distance is related to time and cost incurred in touring from the place of origin to place destination and return home. Travel cost is one of the reasons for tourists to choose their tourist destinations. Tourist tends to pay attention the cost level before touring. This is because not all tourists have an unlimited budget. Based on the theory, it can be formulated a hypothesis as follows:

H2: Travel Cost to Tourist Attraction has a negative effect on the number of tourist visits.

\section{Distance}

According to Mc. Intosh (1995: 298), generally the greater the distance of tourist attraction, the greater the unwillingness to visit tourist attraction. One of the characteristics of tourist attractions is that it can not be moved, so that tourists must go to these tourist attractions. Therefore, accessibility, such as distance from the place of origin to tourist attraction sites and adequate transportation affect the demand for tour. The further the distance, the longer the touring time. Thus, the tourists prefer closer tourist attraction sites from their place of origin. Based on the theory above, it can be formulated the hypothesis as follows:

H3: Distance has a negative effect on the number of tourist visits

\section{Age}

According to the previous research conducted by Lestari (2016), age has a positive effect on the number of tourist visits. The older one's age, the more one's activities, the higher the desire to refresh the soul and body after performing various work routines. Based on the previous research, it can be formulated a hypothesis as follows:

$\mathrm{H} 4$ : Age has a positive effect on the number of tourist visits.

\section{The Most Influential Variable on Tourist Visits}

This study assumes that income is the most influential variable on the number of tourist visits in Owabong Waterpark. According to Sinclair and Stabler (1997), income is highly influential on the 
decision of tourists to make a visit to the tourist attraction. In other words, the greater the person's income, the more likely the person will tour. Therefore, there is a significant relationship between the amount of income and the number of tourist visit, where changes in the amount of income will cause changes in tourist visit.

$\mathrm{H} 5$ : Income is the most influential variable on the number of tourist visits in Owabong Waterpark.

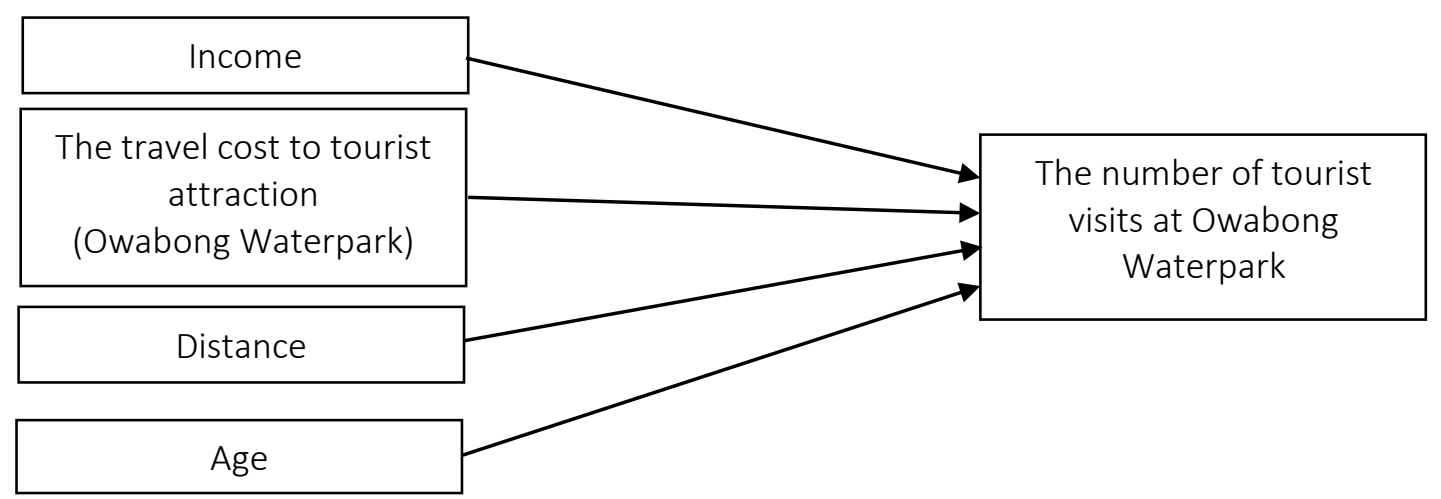

Figure 1. Research Framework

\section{RESEARCH METHOD}

The type of this research is survey research which analyzes the factors affecting the number of tourists who visit Owabong Waterpark attraction in Purbalingga Regency. Survey research is a research conducted by collecting information from a population using questionnaires as a basic data collection tool. This research is a survey research to visitors of Owabong Waterpark using accidental sampling method. This research is conducted in November, 2017. Type of data used in this research is quantitative data. Quantitative data used in this research include income, travel cost to Owabong Waterpark, distance, visitor age, and visiting experience.

Data used in this research can be divided into two types based on the grouping, namely primary data and secondary data. The primary data are collected by asking questions directly to some visitors of Owabong Waterpark Purbalingga Regency. The secondary data in this research are data on the number of Owabong Waterpark visitors sourced from Owabong Regional Company (PD), data on the number of Purbalingga Regency tourists sourced from Department of Youth, Sports and Tourism of Purbalingga Regency, data on the growth of Central Java tourist visits sourced from the data of Central Java BPS (2017), and the data on GRDP on the basis of Constant Price by expenditure component in Purbalingga Regency in 2013-2015. This research used multiple linear regression analysis with double log model.

\section{RESULT}

\section{Regression Result}

To analyze the effect of age, income, distance, and travel cost on the number of tourist visits at Owabong Waterpark multiple linear regression analysis is used with the help of EViews7. Results of multiple linear regression analysis can be seen at Table 1.

Table 1. Multiple Linear Regression Results Using Ordinary Least Square (OLS)

\begin{tabular}{lccc}
\hline Variable & Coefficient & t-Statistic & Prob \\
\hline INCOME & 0.673539 & 7.706408 & 0.0000 \\
TRAVEL COST & -0.034062 & -2.173213 & 0.0323 \\
DISTANCE & -0.016020 & -3.942601 & 0.0002 \\
AGE & 0.008544 & 0.839666 & 0.4032 \\
C & 2.596903 & 7.571788 & 0.0000 \\
\hline
\end{tabular}

Source: Primary Data Processed, 2017 
Based on the Table 1, the following estimation is obtained:

$$
Y=2.5969+0.6735 X_{1}-0.0340 X_{2}-0.0160 X_{3}+0.0085 X_{4}
$$

Note:

$\mathrm{Y}=$ Number of tourist visit

$X_{1}=$ Income

$X_{2} \quad=$ Travel cost to Owabong

$\mathrm{X}_{3}=$ Distance

$\mathrm{X}_{4} \quad=$ Visitor Age

\section{Autocorrelation Test}

Autocorrelation is a correlation between one variable interference with another disturbance variables. To detect whether the presence or absence of Autocorrelation is used Lagrange Multiplier Test (LM Test). The results of the autocolation test can be seen in Table 2 below.

Table 2. Result of Autocorrelation by Breusch-Godfrey LM Test Method
\begin{tabular}{cccc}
\hline F-statistic & 0.635077 & Prob. F $(2,93)$ & 0.5322 \\
Obs*R-squared & 1.347354 & Prob. Chi-Square(2) & 0.5098 \\
\hline
\end{tabular}

The breusch-godfrey method that the model is not affected by autocorrelation, if the Prob.Chi square value is more than 0.05 (5\%). Based on the autocorrelation test results in Table 2 can be seen that the probability of Chi Square greater than 0.05 is 0.5098 so that the model in this research there is no autocorrelation.

\section{Heteroscedasticity Test}

Heteroscedasticity occurs when disturbance variable of the regression model has a variant that is not constant. To detect whether there is Heteroskedasticity on research is used Breusch-Pagan Test. The result of Heteroskedasticity test can be seen in Table 3 below.

\begin{tabular}{cccc} 
Table 3. Result of Heteroskedasticity & by & Breusch-Pagan-Godfrey Method \\
\hline F-statistic & 1.946642 & Prob. F(4,95) & 0.1090 \\
Obs*R-squared & 7.575471 & Prob.Chi-Square(4) & 0.1084 \\
Scaled explained SS & 4.922091 & Prob.Chi-Square(4) & 0.2954 \\
\hline
\end{tabular}

Source: Primary Data Processed, 2017

The Breusch-Pagan-Godfrey Test method there is no symptom of Heteroskedasticity if the probability value of obs * R-squared is greater than $0.05(5 \%)$. Based on the results of Heteroskedasticity test in Table 3 can be seen probability of obs* R-Squared greater than 0.05 is 0.1084 so this research model free of Heteroskedasticity problem.

\section{Multicollinearity Test}

To know whether or not a correlation between the independent variables is used multicollinearity test. In this research to detect whether there is multicollinearity used VIF (Variance Inflation Factor). Multicollinearity test results can be seen in table 4 Below: 
Table 4. Result of Multicollinearity Test by Variance Inflation Factor Method

\begin{tabular}{lc}
\hline Variables & Centered VIF \\
\hline Income & 1.089695 \\
Travel Cost & 1.162398 \\
Distance & 1.179292 \\
Age & 1.075618 \\
\hline urce: Primary Data Processed, 2017
\end{tabular}

If a Centered VIF of less than ten $(<10)$ indicates that there is no multicollinearity. Based on a multicollinearity test of Centered VIF on age, income, distance, and travel cost has Centered VIF less than 10 , it indicates that among explanatory variables do not occur multicollinearity.

\section{Normality Test}

To find out whether in the research model the data is normally distributed, then the Jarque-Bera method is used. The Jarque-Bera method states that the regression model will be normally distributed if the probability is not significant or more than alpha $(>0.05)$. Based on the results of normality test in Figure 1 can be seen the probability of Jarque-Bera greater than 0.05 is 0.514435 so that the study model is normally distributed.

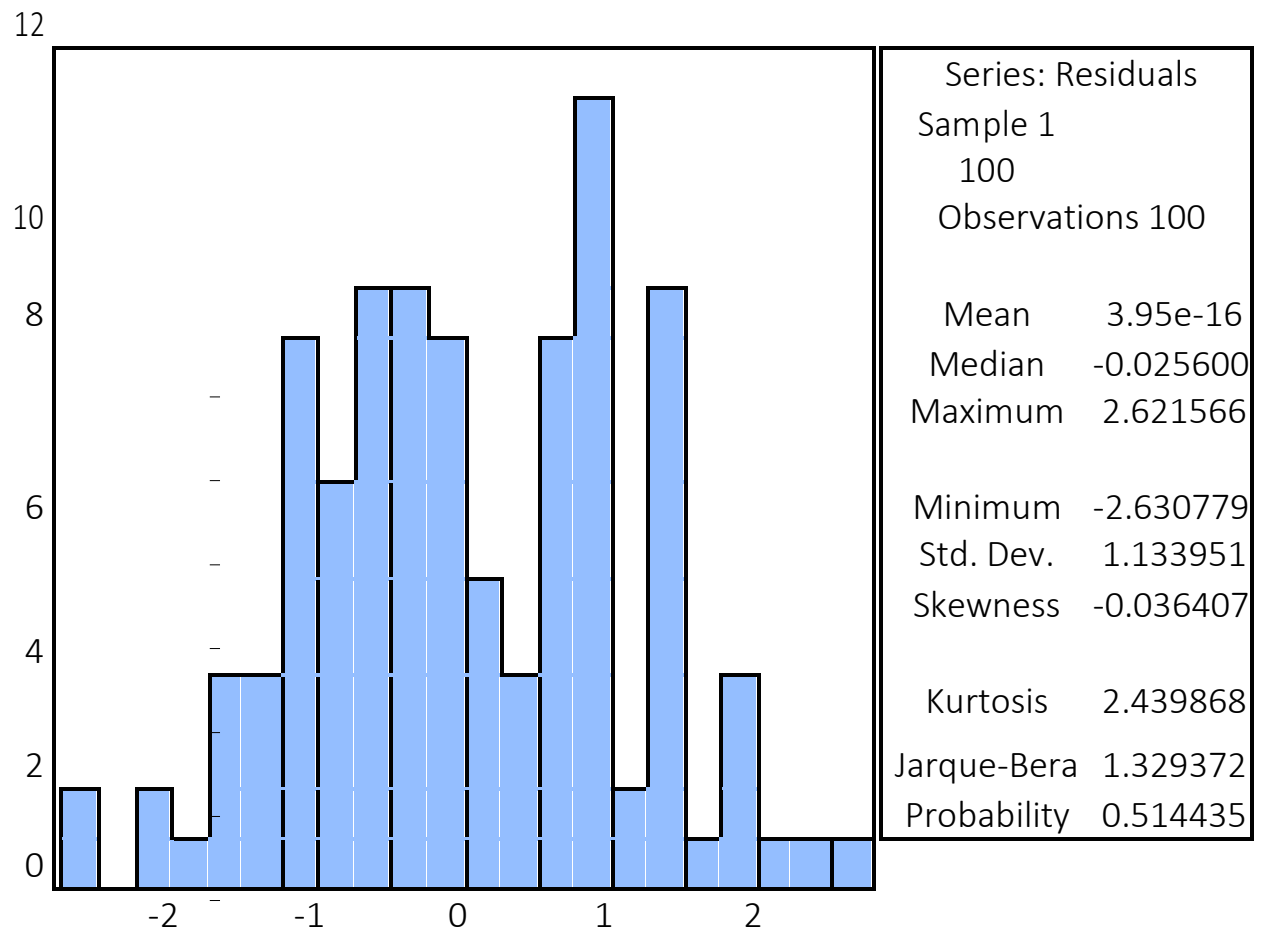

Figure 2. Result of Normality Test by Jarque-Bera Method Source: Primary Data Processed, 2017

\section{Coefficient of determination $R$ squared $\left(R^{2}\right)$}

The value of $R^{2}$ finds out what percentage of variation from dependent variable can explain the independent variable. This test is intended to determine the level of accuracy that best use analysis indicated by the regression coefficient of determination $\left(R^{2}\right)$ between 0 and one $\left(0<R^{2}<1\right)$.

Based on the results of multiple linear test of variables found the number $R$ squared 0.5330 . It can be interpreted that the independent variables of income, travel cost, distance and age can explain $53.30 \%$ on the number of tourist visits in Owabong Waterpark. The remaining $46.70 \%$ is explained by other variables outside the model. 


\section{F-Test}

$\mathrm{F}$ test is used to determine whether the independent variables simultaneously affect the dependent variable.

Hypothesis:

HO: $\beta 1=\beta 2=\beta 3=\beta 4=\beta 5=0$ means the independent variables are simultaneously giving no significant effect on dependent variable.

$\mathrm{H} 1: \beta 1 \neq \beta 2 \neq \beta 3 \neq \beta 4 \neq \beta 5 \neq 0$ means that the independent variables are simultaneously giving significant effect on the dependent variable.

\begin{tabular}{lr}
\multicolumn{2}{c}{ Table 5. Result of F Test } \\
\hline F-statistic & 27.10690 \\
Prob(F-statistic) & 0.000000 \\
Significant & 0.05 \\
\hline Source: Primary Data Processed, 2017
\end{tabular}

If F-statistic greater than F-table or the probability less than 0.05 , it means all those independent variables are simultaneously giving significant effect on the dependent variable. Based on $\mathrm{F}$ test in Table 5 can be seen that the probability is less than 0.05 then $\mathrm{H} 0$ rejected dan $\mathrm{H} 1$ accepted. It means that income, travel cost, distance and age affect simultaneously to the number of tourist visits in Owabong Waterpark.

\section{t-Test}

The $t$ test is used to determine the effect of independent variables to the dependent variable. If the $t-$ statistic is greater than $t$-table then the independent variable has a significant effect on the dependent variable. In this test the significance level used $\alpha=0.05(5 \%)$ with degrees of freedom $\mathrm{df}=$ $\mathrm{n}-\mathrm{k}(100-5=95)$, so t-table is 1.98525 .

Hypothesis:

Ho: $t_{1}=0$, means that the independent variable partially does not have a significant effect on the dependent variable.

$H 1: t_{1} \neq 0$, means that the independent variable partially has a significant effect on the dependent variable.

The criteria of hypothesis testing are:

If $\mathrm{t}$-statistic < $\mathrm{t}$-table, then Ho is accepted, it means that the independent variable does not have significant effect on the dependent variable.

If $\mathrm{t}$-statistic $\geq \mathrm{t}$-table, then $\mathrm{Ho}$ is rejected, it means that the independent variable has a significant effect on the dependent variable.

Based on the result of $\mathrm{t}$ test in Table 6 it can be seen that income has t-statistic of $7.706408>t$ table (1.98525). Therefore, income variable has a positive significant effect on the number of tourist visits in Owabong Waterpark. The hypothesis proposed in this research is can be accepted. Travel cost has t-statistic of $-2.173213>t$ t-table $(-1.98525)$. Therefore, travel cost variable has a negative significant effect on the number of tourist visits in Owabong Waterpark. The hypothesis proposed in this research is can be accepted. Distance has t-statistic of $-3.942601>t$-table (-1.98525). Therefore, distance variable has a negative significant effect on the number of tourist visits in Owabong Waterpark. The hypothesis proposed in this research is can be accepted. Age has t-statistic of $0.839666<\mathrm{t}$-table (1.98525). Therefore, age variable has insignificant effect on the number of tourist visits in Owabong Waterpark. Based on Table 4.1 shows that the age of most respondents to Owabong Waterpark is $17-25$ years old with the total amount 52 percent. But, the increasing of 
visitor age indicate decreasing on total of visitors. The hypothesis proposed in this research is cannot be accepted.

Table 6. Result of t Test

\begin{tabular}{lccc}
\hline & t-statistics & t-table & Explanation \\
\hline Constant & 7.571788 & -1.98525 & - \\
Income & 7.706408 & 1.98525 & Significant \\
Travel Cost & -2.173213 & -1.98525 & Significant \\
Distance & -3.942601 & -1.98525 & Significant \\
Age & 0.839666 & 1.98525 & Insignificant \\
\hline \multicolumn{4}{c}{ Source: Primary Data Processed, 2017 }
\end{tabular}

\section{DISCUSSION}

\section{The Effect of Income on Number of Tourist Visits in Owabong Waterpark}

Income has a positive significant effect to the number of tourist visits in Owabong Waterpark with regression coefficient value of 0.6735 . It shows that the addition of income of IDR 1 million to the number of tourist visits increase of 0.6735 times with the assumption that other independent variables is constant. The relationship between income and the number of tourist visits corresponds with the hypothesis proposed. The results of this study in accordance with research conducted by Lestari (2016) that income has a positive effect on the frequency of visits to Maimun Castle. This indicates that people's income level will have an effect on their decision to visit Owabong Waterpark. Therefore, the management is expected to frequently conduct promotions, such as discounted admission ticket to reach all elements of community both high and low income. In addition, discounts on Longweekend for example from $50 \%$ to $75 \%$ discount, when the holiday falls on Friday, then the management of Owabong Waterpark makes discount on admission ticket on the longweekend that is on Friday, Saturday and Sunday. So, that it can increase the number of visitors and revenue.

Income is highly influential on the decision of tourists to make a visit to the tourist attraction. In other words, the greater the person's income, the more likely the person will tour. Therefore, there is a significant relationship between the amount of income and the number of tourist visit, where changes in the amount of income will cause changes in tourist visit.

\section{The Effect of Travel Cost on Number of Tourist Visits in Owabong Waterpark}

Travel Cost has a negative significant effect to the number of tourist visits in Owabong Waterpark with regression coefficient value of -0.0340 . It shows that the addition of travel cost of IDR ten thousand lead to the number of tourist visits decrease of 0.0340 times with the assumption that other independent variables is constant. The relationship between travel cost and the number of tourist visits corresponds with the hypothesis proposed. The results of this study in accordance with research conducted by Lestari (2016) that travel cost has a negative effect on the frequency of visits to Maimun Castle. This indicates that travel cost will have an effect on decision to visit Owabong Waterpark. Therefore, the management should conduct more vigorous and attractive promotions. The promotions include complete information about vehicles and spots with attractive pictures and persuasive language to attract the visitors, complete information about ticket prices, prices for vehicles, food and beverage prices around the attraction, and promotion about the most popular souvenirs at Owabong Waterpark. This can be used as an overview about the attraction for the prospective visitors who intend to visit Owabong Waterpark, especially the information about the travel cost.

Travel cost is one of the reasons for tourists to choose their tourist destinations. Tourist tends to pay attention the cost level before touring. This is because not all tourists have an unlimited budget. 


\section{The Effect of Distance on Number of Tourist Visits in Owabong Waterpark}

Distance has a negative significant effect to the number of tourist visits in Owabong Waterpark with regression coefficient value of -0.0160 . It shows that the addition of distance of 1 kilometer lead to the number of tourist visits decrease of 0.0160 times with the assumption that other independent variables is constant. The relationship distance and the number of tourist visits corresponds with the hypothesis proposed. The results of this study in accordance with research conducted by Anna and Saputra (2017) that distance has negative effect on the number of visits in Cederawasih Bay National Park. This indicates that distance will have an effect on decision to visit Owabong Waterpark. The management should conduct more vigorous and attractive promotions, especially in social media so that Owabong Waterpark is better known by the community outside Purbalingga and it is not only visited by local tourists, but also foreign tourists. In addition, Owabong Waterpark cooperates with travel agencies to hold a tour package promo, especially for areas outside central Java province to attract visitors from areas outside central Java.

According to Mc. Intosh (1995: 298), generally the greater the distance of tourist attraction, the greater the unwillingness to visit tourist attraction. One of the characteristics of tourist attractions is that it cannot be moved, so that tourists must go to these tourist attractions.

\section{The Effect of Age on Number of Tourist Visits in Owabong Waterpark}

Based on the result of t test with significance level $\alpha=5 \%$, it is known that age has insignificant effect on the number of tourist visits in Owabong Waterpark with regression coefficient value of 0.0085 . It shows that visitor age does not have an effect on the number of tourist visits in Owabong Waterpark. The insignificant effect of age variable on the number of tourist visits in Owabong Waterpark is because based on Table 4.1 shows that the age of most respondents is 17-25 years old with the total amount 52 percent. But, the increasing of visitor age indicate decreasing on total of visitors. While the least is 53-61 years old that is 4 percent.

Age also determines a person's interest to tour, because age is a reflection to consider a person's decision to make a tour, whether a person needs to tour or not. The hypothesis in this research cannot be accepted because the relationship between age variable with the number of tourist visits variables not corresponding with the hypothesis proposed.

\section{The Most Influential Variable on Number of Tourist Visits in Owabong Waterpark}

In order to know which variable has the greatest influence in model can be seen from the coefficient of independent variable. The variable that has the greatest coefficient means having the greatest influence on the independent variable. Among all variables, income variable which has the largest coefficient is 0.6735 . It means that income variable is the most influential variable on the number of tourist visits in Owabong Waterpark.

\section{CONCLUSION}

Based on the results of the research in the previous chapter it can be concluded as follows:

(1) Income has positive and significant effect on the number of tourist visits in Owabong Waterpark.

(2) Travel cost has negative and significant effect on the number of tourist visits in Owabong Waterpark.

(3) Distance has negative and significant effect on the number of tourist visits in Owabong Waterpark.

(4) Age has insignificant effect on the number of tourist visits in Owabong Waterpark.

(5) Income is the most influential variable affecting the number of tourist visits in Owabong Waterpark because it is proven to have the largest coefficient.

\section{IMPLICATION}

Income is the most influential variable and has positive effect on tourist visits at Owabong Waterpark. Based om the result of this research that the income owned by respondents each month 
is mostly by the respondents who have average income less than IDR1,475,000.00. This indicates that people's income level will have an effect on their decision to visit Owabong Waterpark. Therefore, the management is expected to frequently conduct promotions, such as discounted admission ticket to reach all elements of community both high and low income. In addition, discounts on Longweekend for example from $50 \%$ to $75 \%$ discount, when the holiday falls on Friday, then the management of Owabong Waterpark makes discount on admission ticket on the longweekend that is on Friday, Saturday and Sunday. Promotions in school in Purbalingga Regency. So, that it can increase the number of visitors and revenue.

Travel Cost has a negative significant effect to the number of tourist visits in Owabong Waterpark. This indicates that travel cost will have an effect on decision to visit Owabong Waterpark. Therefore, the management should conduct more vigorous and attractive promotions. The promotions include complete information about vehicles and spots with attractive pictures and persuasive language to attract the visitors, complete information about ticket prices, prices for vehicles, food and beverage prices around the attraction, and promotion about the most popular souvenirs at Owabong Waterpark. This can be used as an overview about the attraction for the prospective visitors who intend to visit Owabong Waterpark, especially the information about the travel cost.

Distance has a negative significant effect to the number of tourist visits in Owabong Waterpark. Therefore, owabong management should conduct more vigorous and attractive promotions, especially in social media so that Owabong Waterpark is better known by the community outside Purbalingga and it is not only visited by local tourists, but also foreign tourists. In addition, Owabong Waterpark cooperates with travel agencies to hold a tour package promo, especially for areas outside central Java province to attract visitors from areas outside central Java.

\section{RESEARCH LIMITATION}

The factors that influence the number of tourist visits at Owabong Waterpark in this research only consist of four variables, that is income, travel cost, distance, and visitor age. While there are other factors that can affect the the number of tourist visits in Owabong Waterpark. Samples only 100 respondents using Accidental Sampling, therefore in the next research hopefully get a bigger sample, so it will be closer to the actual conditions.

\section{REFERENCES}

Ahmadia, E. (2017). The effect of competitive advantages and service quality on satisfaction and loyalty visitor of "Owabong" Purbalingga Water Tourism Object. Daya Saing, 19(1), 37-46.

Anna and Saputra. (2017). Economic valuation of whale shark tourism in Cenderawasih Bay National Park, Papua, Indonesia. Biodiversitas, 18(3),1026-1034.

BPS. (2014). Central Java regional statistic 2015. Retrieved from: jateng.bps.go.id/index.php/ linkTabelStatis/924 (accesed on 15 August 2017).

Cai, Y. and Evans, M. (2018). Informal transfers in comparisons of income distributions: Lessons from rich and middle-income countries. Journal of Income Distribution, 26(2), 1-20.

Lestari, L. (2016). Factors Affecting the frequency of tourist visits to Istana Maimun Medan. Thesis. Universitas Pasundan.

Li, X., Lu, L., and Chi, C.G.Q. (2018). Examining incentive travelers: How motivation affects organizational commitment. International Journal of Tourism Research.

Owabong. (2017). A brief history. Retrieved from: http://owabong.co.id/zona/waterpark/ (accessed on 15 August 2017).

Puspita, D.R., Dharma, P., and Idanati, R. (2016). Optimization model of the role of chairman of the neighborhood in preventing the religion. Community, Culture and Politic, 29(4), 181-190.

Raisova, M. and Ducova, J. (2014). Economic growth-supply and demand perspective. Procedia Economics and Finance, 15(2014) 184-191.

Trenggonowati. (2011). Microeconomics. Yogyakarta: BPFE. 